\title{
The combined effect of anticholinesterase compound DDVP and its antidote cholinesterase reactivator carboxim on implementation of cholinergic anti-inflammatory pathway
}

\begin{abstract}
Experiments on random-bred albino mice showed that the acute intoxication of anticholinesterase compounds (DDVP, $0.75 \mathrm{LD}_{50}$ ) is implemented the cholinergic antiinflammatory pathway (reduced mortality of mice from sepsis and the blood concentration of pro-inflammatory cytokines TNF- $\alpha$, IL-1 $\beta$, IL-6). Sepsis caused by the intraperitoneal administration of saline diurnal culture of $E$. coli $\mathrm{O} 157: \mathrm{H} 7\left(2.5 \times 10^{9} \mathrm{CFUs}\right)$. The use of the cholinesterase reactivator carboxim $(15 \mathrm{mg} / \mathrm{kg})$-antidote of organophosphorus compounds - after acute intoxication of DDVP diminished affect the implementation of the cholinergic anti-inflammatory pathway.
\end{abstract}

Keywords: anti-inflammatory pathway, sepsis, E. coli, anticholinesterase compounds, cholinesterase reactivator carboxim
Volume 7 Issue 6 - 2019

\author{
Pavel Franzevich Zabrodskii \\ Saratov Medical University “REAVIZ”, Saratov, Russia
}

Correspondence: Pavel Franzevich Zabrodskii, Saratov Medical University “REAVIZ”, Saratov, Russia, Email pfzabrodsky@gmail.com

Received: October 26, 2019 | Published: November 26, 2019

\section{Introduction}

Anticholinesterase compounds (organophosphate compounds$\mathrm{OPC}$, anticholinesterase drugs) are widely used in agriculture, various industries and households, in medicine. OPC can cause environmental pollution, as well as acute and chronic intoxications. ${ }^{1-7}$ Cholinergic stimulation, as we established in $1987^{2}$ and in subsequent studies, significantly reduces the mortality of white mice from sepsis caused by intraperitoneal or intrapulmonary administration, respectively of E. coli and P. vulgaris. ${ }^{3-5,8}$ Thus, the cholinergic anti-inflammatory mechanism has been discovered in 1987, ${ }^{2}$ named "cholinergic antiinflammatory pathway» in $2002^{9}$ after the research its implementation at the organismal, cellular and subcellular levels., ${ }^{3,4,9,10}$ It should be noted that in 1995 it was proved the possibility of cholinomimetics for emergency activation of antimicrobial resistance of the organism in sepsis. ${ }^{3,4}$ In the future, the study of the cholinergic anti-inflammatory pathway caused by the action of acetylcholine on $\alpha 7 n$-acetylcholine receptors $(\alpha 7 \mathrm{nAChRs})$ cells of the monocyte-macrophage system (MMC), followed by inhibition of the production by the cells of proinflammatory cytokines (TNF- $\alpha$, IL- $1 \beta$, IL- 6 ) and reduced mortality from sepsis were devoted hundreds of articles various authors. ${ }^{5,9-18}$ Reduced production of TNF- $\alpha$, IL-1 $\beta$, IL-6 (anti-inflammatory effect occurrence) for cholinergic anti-inflammatory pathway is provided kinase JAK2, transcription factor STAT3, NF- $\mathrm{kB}$ transcription factor). ${ }^{10,16-18}$ The aim of the study was to evaluate the effect of acute intoxication of anticholinesterase compound in combination with its antidote cholinesterase reactivator carboxim on the mortality of mice from sepsis caused by experimental peritonitis (E. coli), and the concentration of pro-inflammatory cytokines TNF $\alpha$, IL- $1 \beta$ and IL-6 in blood.

\section{Materials and methods}

Experiments were performed on random-bred albino mice of both sexes weighing 18-22 g. Control group of mice (control group $1, \mathrm{n}=8$ ) received i.p. $2.0 \mathrm{ml}$ isotonic sodium chloride solution (saline) $2 \mathrm{~h}$ after subcutaneous administration of $0.5 \mathrm{ml}$ saline. The second group of mice (control group 2, $\mathrm{n}=50$ ) was injected subcutaneously once with saline $(0.5 \mathrm{ml})$, after $2 \mathrm{~h}$ mice received $2.5 \times 10^{9}$ CFUs in $2.0 \mathrm{ml}$ of saline diurnal culture of E. coli O157:H7 (sepsis modeling). $)^{2,4,9,16-18,20}$ Mice of the third group $(\mathrm{n}=40)$ were injected with OPC-DDVP (O, O-dimethyl-O-2,2-dichlorovinyl phosphate) (Sigma-Aldrich) intramuscularly once at a dose of $0.75 \mathrm{LD}_{50}$ in $0.5 \mathrm{ml}$ of a $0.25 \%$ solution of dimethyl sulfoxide (DMSO). DDVP was dissolved in DMSO, $0.25 \%$ aqueous solution containing a toxicant was prepared. The $\mathrm{LD}_{50}$ DDVP was $52.5 \pm 3.3 \mathrm{mg} / \mathrm{kg}$. The fourth group of mice $(\mathrm{n}=25)$ received cholinesterase reactivator OPC of antidote carboxim (5-[[[[2-[Benzyl(dimethyl)ammonio]ethyl]amino] carbonyl]-2-[(hydroxymino)methyl]-1-methylpyridinium dichloride) (Pharmzaschita Research and Production Center "Pharmzaschita", Russia) at a dose of $15 \mathrm{mg} / \mathrm{kg}$ in $0.5 \mathrm{ml}$ saline (single subcutaneous injection). The fifth group of mice $(n=45)$ received DDVP intramuscularly once at a dose of $0.75 \mathrm{LD}_{50}$ and carboxim $(15 \mathrm{mg} / \mathrm{kg}$, single subcutaneous injection) 5-10 minutes after the administration of OPC (DDVP).

The concentration of TNF- $\alpha$, IL1 $\beta$ and IL- 6 was studied in blood plasma of all groups of mice (groups 1-5) 4 and $24 \mathrm{~h}$ after the administration of $E$. coli (sepsis modeling) by enzyme immunosorbent assay (ELISA) using kits (ELISA Kits MyBioSoure) in accordance with the manufacturer's instructions. Monoclonal antibodies MyBioSoure (TNF- $\alpha$, IL1 $\beta$, IL-6 - \#MBS494184, \#MBS494492, \#MBS335516) were used to determine the concentration of proinflammatory cytokines. Blood for research was taken from the retroorbital venous sinus. The data obtained were processed statistically using the Student's t-test. Differences between the parameters were considered reliable at $\mathrm{p}<0.05$. 


\section{Results}

Acute intoxication of OPC (DDVP, $0.75 \mathrm{LD}_{50}$ ), combined effect of OPC and carboxim $(15 \mathrm{mg} / \mathrm{kg}) 2 \mathrm{~h}$ before the sepsis modeling caused a significant decrease in mortality of mice after $4 \mathrm{~h}$ compared with the control group 2 (sepsis), respectively, in 4.80 and 1.80 times $(\mathrm{p}<0.05)$ (by 38.0 and $21.3 \%$ ), and after 24 h-in 1.68 and 1.33 times (by 32.5 and $20.0 \%)(\mathrm{p}<0.05)$, respectively. The administration of carboxim ( $2 \mathrm{~h}$ before the sepsis modeling) did not significantly $(\mathrm{p}>0.05)$ reduce the mortality of mice after 4 and $24 \mathrm{~h}$ (after the administration of $E$. coli). The obtained research results indicate that the administration of carboxim after acute intoxication of OPC (before sepsis modeling) diminished the effect of OPC, which causes a reduction in the mortality of mice after sepsis modeling (Table 1).

The concentrations of cytokines TNF- $\alpha$, IL-1 $\beta$ and IL-6 after sepsis modeling (control group 2) significantly increased in the blood of mice after $4 \mathrm{~h}$ compared to control group 1 (intact animals), respectively, at $17.0 ; 19.9$ and 53.7 times $(\mathrm{p}<0.05)$, the concentrations of TNF- $\alpha$, IL- $1 \beta$ and IL- 6 after $24 \mathrm{~h}$ compared with their level after 4 $\mathrm{h}$ significantly decreased, exceeding the parameters of intact animals (group 1) in $1.3(\mathrm{p}>0.05), 4.7$ and 6.5 times $(\mathrm{p}<0.05)$, respectively (Table 2).

Table I Combined effect of OPC (DDVP, $\left.0.75 \mathrm{LD}_{50}\right)$ and carboxim $(15 \mathrm{mg} / \mathrm{kg})$ on the mortality of mice from sepsis $(\mathrm{M} \pm \mathrm{m})$

\begin{tabular}{lll}
\hline \multirow{2}{*}{ Series of experiments } & \multicolumn{2}{l}{ Term study of mortality after the administration of E. coli, $\mathbf{h}$} \\
\cline { 2 - 3 } & $\mathbf{4}$ & $\mathbf{2 4}$ \\
\hline Sepsis (control group $2, \mathrm{n}=50)$ & $48,0 \pm 7,0$ & $80,0 \pm 5,7$ \\
DDVP + sepsis (group $3, \mathrm{n}=40)$ & $10.0 \pm 4.7^{*}$ & $47.5 \pm 7,9^{*}$ \\
Carboxim + sepsis (group 4, $\mathrm{n}=25)$ & $36.0 \pm 9,6$ & $68.0 \pm 9,3$ \\
DDVP + carboxim + sepsis (group 5, $\mathrm{n}=45)$ & $26.7 \pm 6.6^{* *}$ & $60,0 \pm 7,3^{*}$ \\
\hline
\end{tabular}

$*-p<0,05$ as compared to control (group 2)

Table 2 Combined effect of OPC (DDVP, 0.75 LD $_{50}$ ) and carboxim $(15 \mathrm{mg} / \mathrm{kg}$ ) on concentrations of proinflammatory cytokines in blood of mice after sepsis modeling, $\mathrm{pg} / \mathrm{ml}(\mathrm{M} \pm \mathrm{m} ; \mathrm{n}=6-8)$

\begin{tabular}{lllllll}
\hline \multirow{2}{*}{ Series of experiments } & TNF $\alpha$ & \multicolumn{3}{c}{ ILI $\beta$} & IL-6 \\
\cline { 2 - 7 } & $\mathbf{4}$ & $\mathbf{2 4}$ & $\mathbf{4}$ & $\mathbf{2 4}$ & $\mathbf{4}$ & $\mathbf{2 4}$ \\
\hline Control group I & $40 \pm 6$ & $42 \pm 7$ & $29 \pm 5$ & $25 \pm 5$ & $41 \pm 6$ & $37 \pm 6$ \\
Sepsis (control group 2) & $680 \pm 87^{\mathrm{a}}$ & $53 \pm 8^{\mathrm{c}}$ & $577 \pm 72^{\mathrm{a}}$ & $118 \pm 24^{\mathrm{ac}}$ & $2200 \pm 250^{\mathrm{a}}$ & $242 \pm 36^{\mathrm{ac}}$ \\
DDVP + sepsis (group 3) & $215 \pm 26^{\mathrm{ab}}$ & $46 \pm 7^{\mathrm{c}}$ & $252 \pm 35^{\mathrm{ab}}$ & $59 \pm 8^{\mathrm{abc}}$ & $331 \pm 42^{\mathrm{ab}}$ & $94 \pm 11^{\mathrm{abc}}$ \\
Carboxim + sepsis (group 4) & $520 \pm 65^{\mathrm{a}}$ & $38 \pm 7^{\mathrm{c}}$ & $378 \pm 63^{\mathrm{a}}$ & $72 \pm 12^{\mathrm{ac}}$ & $1600 \pm 210^{\mathrm{a}}$ & $161 \pm 29^{\mathrm{ac}}$ \\
DDVP + carboxim + sepsis (group 5) & $325 \pm 30^{\mathrm{abd}}$ & $35 \pm 5^{\mathrm{c}}$ & $355 \pm 33^{\mathrm{abd}}$ & $63 \pm 7^{\mathrm{abc}}$ & $605 \pm 64^{\mathrm{abd}}$ & $105 \pm 12^{2^{\mathrm{abc}}}$ \\
\hline
\end{tabular}

Note: 4 and 24 - after sepsis modeling, h; ${ }^{\mathrm{a}}$-p $<0,05$ as compared to control (group I); ${ }^{\mathrm{b}}-\mathrm{p}<0,05$ as compared to the corresponding parameter in sepsis (control group 2); ${ }^{\mathrm{c}}-\mathrm{p}<0,05$ as compared to the $4 \mathrm{~h}$; ${ }_{-}^{\mathrm{d}} \mathrm{p}<0,05$ as compared to the corresponding parameter in group 3

Acute intoxication of OPC (DDVP) decreased the TNF- $\alpha$, IL-1 $\beta$ and IL-6 blood concentrations $4 \mathrm{~h}$ after sepsis modeling (group 3) compared to the control group 2 (sepsis without the use of drugs), respectively, by $3.16 ; 2.29$ and 6.65 times $(p<0.05)$. At the same time, the concentrations of proinflammatory cytokines in the blood significantly $(p<0.05)$ exceeded the corresponding parameters of the control group 1. The concentrations of TNF- $\alpha$, IL-1 $\beta$ and IL-6 $24 \mathrm{~h}$ after sepsis modeling decreased in comparison with these parameters after $4 \mathrm{~h}$, remaining below group 2 values in 1.15 ( $\mathrm{p}>0.05), 2.00$ and 2.57 times $(p<0.05)$, respectively. The parameters of TNF- $\alpha$, IL$1 \beta$ and IL-6 after administration of carboxim in $4 \mathrm{~h}$ and $24 \mathrm{~h}$ after modeling sepsis (group 4) were not significantly reduced ( $p>0.05)$ compared with the parameters of the control group 2.

The values of TNF- $\alpha$, IL-1 $\beta$ and IL-6, when using OPC (DDVP, $0.75 \mathrm{LD}_{50}$ ) and its antidote carboxim (combined effect) decreased $4 \mathrm{~h}$ after the sepsis modeling (group 5) compared to the parameters of the control group 2, respectively, in 2.09; 1.63 and 3.64 times $(p<0.05)$. The reduction of content of proinflammatory cytokines in the blood was established $24 \mathrm{~h}$ after the sepsis modeling compared with the corresponding values after $4 \mathrm{~h}$, while the concentrations of TNF- $\alpha$, IL-
$1 \beta$ and IL-6 remained higher than the values of group 1, respectively, in $1.26(p>0,05) ; 4.72$ and 6.54 times $(p<0.05)$. The IL-1 $\beta$ and IL-6 blood concentrations in groups 3,4 and 5 were significantly higher $(p<0.05)$ than the corresponding values of the control group 1 . The TNF- $\alpha$ blood concentrations in these groups were significantly higher $(\mathrm{p}<0.05)$ only $4 \mathrm{~h}$ after the sepsis modeling. The values of TNF- $\alpha$, IL$1 \beta$, and IL- 6 in blood $4 \mathrm{~h}$ after sepsis modeling and combined action of OPC and carboxim (group 5) compared to acute OPC intoxication (DDVP, after sepsis modeling, group 3) were significantly higher $(p<0.05)$, but these values were significantly lower $(p<0.05)$ in group 2 (sepsis modeling).

\section{Discussion}

The administration of carboxim practically did not reduce the mortality of mice, as well as the concentrations of cytokines TNF- $\alpha$, IL- $1 \beta$ and IL- 6 after sepsis modeling. This is due to the ability of carboxim to restore the activity of acetylcholinesterase, as a result of which the concentration of acetylcholine in synapses of the parasympathetic nervous system increases to a lesser extent than without the use of carboxim, and the effect of cholinergic anti- 
inflammatory pathway decreases (to reduce the effect of acetylcholine on $7 \mathrm{nAChRs}$ of MMS cells). ${ }^{5,9,10}$ The data we have provided on the administration of carboxim after acute intoxication of OPC (before sepsis modeling) diminished the effect of OPC, which causes a reduction in the mortality of mice after sepsis modeling, as well as by the results of our studies, which show that the values of TNF- $\alpha$, IL-1 $\beta$, and IL-6 in blood $4 \mathrm{~h}$ after sepsis modeling and combined action of OPC and carboxim compared to acute OPC intoxication after sepsis modeling were significantly higher.

After OPC acute intoxication after sepsis modeling mouse mortality is significantly reduced after 4 and $24 \mathrm{~h}$ compared with the control (sepsis). OPC acute intoxication of decreased the TNF- $\alpha$, IL-1 $\beta$ and IL-6 blood concentrations after sepsis modeling compared to the control group (sepsis without the use of drugs). Numerous studies have shown that the established effects are associated with acetylcholine m1AChRs activation of the brain, ${ }^{18,21} \alpha 7 \mathrm{nAChRs}$ of MMS cells, nAChRs of adrenal medulla and other mechanisms. ${ }^{9-11,14,16,17,19}$ The implementation of the reduction of pro-inflammatory cytokines TNF- $\alpha$, IL-1 $\beta$, IL-6, and others (the occurrence of anti-inflammatory effect) is provided by JAK2 kinase, STAT3 transcription factor, transcription factor NF- $\mathrm{kB}$ ). ${ }^{5,10,15-19}$ In addition, the decrease in mortality from sepsis after acute intoxication of OPC due to the suppression of the synthesis of proinflammatory cytokines is also associated with the effect of corticosteroids (activation of the hypothalamic-pituitaryadrenal system) $)^{5,8,11}$

\section{Acknowledgments}

None.

\section{Conflicts of interest}

Author declares that there is no conflict of interest.

\section{References}

1. Tremolada P, Finizio A, Villa S, et al. Quantitative inter-specific chemical activity in the aquatic environment. Aquat Toxicol. 2004;67(1):87-103.

2. Zabrodskii PF. Effect of armin on nonspecific resistance factors of the body and on the primary humoral immune response. Farmakol Toksikol. 1987;50(1):57-60.

3. Zabrodskii PF. Variation in antiinfectious nonspecific resistance of the organism caused by cholinergic stimulation. Bull Exp Biol Med. 1995;120(2):809-811.

4. Zabrodskii PF. Change in the non-specific anti-infection resistance of the body exposed to cholinergic stimulation. Bull Exp Biol Med. 1995;120(8):164-166.

5. Zabrodskii PF. Immunotoxicology of organophosphorus compounds. Saratov; 2016. 289 p.

6. Zabrodskii PF, Germanchuk VG. Role of activation of the sympathoadrenal system during the poisoning of organophosphorus compounds. Bull Exp Biol Med. 2001;132(4):966-968.
7. Zabrodskii PF, Kirichuk VF, Germanchuk VG. Role of anticholinesterase mechanism in suppression of antibody formation during acute poisoning with organophosphorus compounds. Bull Exp Biol Med. 2001;131(5):467-469.

8. Zabrodskii PF, Mandych VG. Immunotoxicology of xenobiotics. Saratov Military Institute of Biological and Chemical Safety (2007): 420.

9. Bernik TR, Friedman SG, Ochani M, et al. Pharmacological stimulation of the cholinergic anti-inflammatory pathway. J Exp Med. 2002;195(6):781-788

10. Borovikova LV, Ivanova $\mathrm{S}$, Zhang $\mathrm{M}$, et al. Vagus nerve stimulation attenuates the systemic inflammatory response to endotoxin. Nature. 2000;405(6785):458-462.

11. Bonaz BL, Bernstein CN. Brain-gut interactions in inflammatory bowel disease. Gastroenterology. 2013;144(1):36-49.

12. Fernandez R, Nardocci G, Navarro C, et al. Neural reflex regulation of systemic inflammation: potential new targets for sepsis therapy. Front Physiol. 2014;5:489.

13. Reardon C. Neuro-immune interactions in the cholinergic antiinflammatory reflex. Immunol Lett. 2016;178:92-96.

14. Wang $\mathrm{H}$, Yu M, Ochani $M$, et al. Nicotinic acetylcholine receptor alpha7 subunit is an essential regulator of inflammation. Nature. 2003;421(6921):384-388

15. Zabrodskii PF. Effect of acetylcholine on mortality of mice from sepsis and proinflammatory cytokine production. Bull Exp Biol Med. $2011 ; 150(3): 340-342$.

16. Zabrodskii PF, Gromov MS, Maslyakov VV. Effect of $\alpha 7 n$-Acetylcholine Receptor Activation and Antibodies to TNF- $\alpha$ on Mortality of Mice and Concentration of Proinflammatory Cytokines during Early Stage of Sepsis. Bull Exp Biol Med. 2015;159(6):740-742.

17. Zabrodskii PF, Gromov MS, Maslyakov VV. Role of $\beta 2$-adrenoreceptors in adrenergic anti-Inflammatory mechanism in sepsis. Bull Exp Bio Med. 2016;163(6):718-721.

18. Zabrodskii PF, Gromov MS, Maslyakov VV, et al. Combined Effects of M1 Muscarinic Acetylcholine Receptor Agonist TBPB and $\alpha 7 \mathrm{n}$ Acetylcholine Receptor Activator GTS-21 on Mouse Mortality and Blood Concentration of Proinflammatory Cytokines in Sepsis. Bull Exp Biol Med. 2017;162(6):750-753.

19. Zabrodskii PF, Gromov MS, Maslyakov VV. Combined Effect of NF- $\kappa B$ Inhibitor and $\beta 2$-Adrenoreceptor Agonist on Mouse Mortality and Blood Concentration of Proinflammatory Cytokines in Sepsis. Bull Exp Biol and Med. 2018;165(4):445-448.

20. Song DJ, Huanq XY, Ren LC, et al. Effect of lentiviral vector encoding on triggering receptor expressed on myeloid cells 1 on expression of inflammatory cytokine in septic mice infected by Bacteroides fragilis. Zhonghua Shao Shang Za Zhi. 2009;25(1):36-41. 